\title{
CORRELATION BETWEEN ULTRASONOGRAPHIC FEATURES AND HISTOPATHOLOGICAL FINDINGS OF BREAST LESIONS IN BIOPSIES
}

\author{
Correlação entre características ultrassonográficas e achados
} histopatológicos de lesões mamárias em biópsias

\author{
Laila Carolline Freitas e Silva*, Josmara Ximenes Andrade Furtado²
}

\section{ABSTRACT}

Imaging exams are fundamental tools to characterize palpable lesions and to early detect those not identified on the physical examination. However, the correct interpretation of these findings should be done by correlating them with the probable histological diagnosis of the lesion, and performing the appropriate treatment in a timely manner. The Breast Imaging-Reporting and Data System $\left(\right.$ BIRADS $\left.^{\circledR}\right)$ is the system used for this association, which characterizes the findings in mammography, ultrasonography and mammary magnetic resonance images, classifying them according to the probability of malignancy. Objective: To correlate imaging features of breast nodules, evidenced by ultrasonography and classified according to BIRADS ${ }^{\circledR}$, with the histopathological examination results of material obtained through thick needle biopsy of patients from the mastology ambulatory of the Maternity School Assis Chateaubriand that confirm this predictive value of the imaging examination and the impact on surgical indications. Results: We analyzed 110 patient's medical records that fit the inclusion criteria and found that more than $97 \%$ of lesions with low suspicion of malignancy, BIRADS ${ }^{\circledR}$ 4A, presented a benign histopathological result. However, all patients with images of nodules with high suspicion of malignancy had histopathological diagnosis of invasive carcinoma. In conclusion, the ultrasonographic features of breast lesions have high predictive value in the final diagnosis of the lesion, supporting the decision of conduct in adequate time in each situation.

KEYWORDS: Ultrasonography, mammary; breast; biopsy, needle.

\section{RESUMO}

Os exames de imagem são ferramentas fundamentais na caracterização de lesões palpáveis e na detecção precoce daquelas não identificadas ao exame físico. Porém, é necessária a interpretação correta desses achados, correlacionando com o provável diagnóstico histológico da lesão, realizando tratamento adequado e em tempo certo. O Breast Imaging-Reporting and Data System (BIRADS ${ }^{\circledR}$ ) é o sistema utilizado para essa relação, caracterizando os achados em imagens de mamografia, ultrassonografia e ressonância magnética mamária e classificando-os de acordo com a probabilidade de malignidade. Objetivo: Correlacionar características imagenológicas de nodulações mamárias, evidenciadas por ultrassonografia e classificadas de acordo com o BIRADS ${ }^{\circledR}$, $\operatorname{com}$ os resultados dos exames histopatológicos de material obtido através de biópsia de agulha grossa de pacientes do ambulatório de mastologia da Maternidade Escola Assis Chateaubriand, confirmando esse valor preditivo do exame de imagem e o impacto nas indicações cirúrgicas. Resultados: Foram analisados 110 prontuários de pacientes que se encaixavam nos critérios de inclusão e constatou-se que mais de 97\% das lesões com baixa suspeição de malignidade, BIRADS ${ }^{\circledR} 4$ A, apresentaram resultado benigno no exame histopatológico. Entretanto, todas as pacientes com imagens de nódulos com alta suspeição de malignidade tiveram diagnóstico histopatológico de carcinoma invasor. Pode-se concluir que as características ultrassonográficas das lesões mamárias têm alto valor preditivo no diagnóstico final da lesão, fundamentando a decisão de conduta em tempo adequado em cada situação.

PALAVRAS-CHAVE: Ultrassonografia mamária; mama; biópsia por agulha.

Study performed at Universidade Federal do Ceará (UFC) - Fortaleza (CE), Brazil.

${ }^{1}$ Mastology Program, Universidade Federal do Ceará (UFC) - Fortaleza (CE), Brazil.

${ }^{2}$ Maternity School Assis Chateaubriand, UFC - Fortaleza (CE), Brazil.

*Corresponding author: lailacarolline@gmail.com

Conflict of interest: nothing to declare.

Received on: 02/05/2017. Accepted on: 05/22/2017 


\section{INTRODUCTION}

The detection of breast nodules for diagnosing cancer precursor lesions before clinical manifestations is essential, considering its early discovery allows a less aggressive treatment and yet more effective for these diseases.

In recent years, imaging studies have greatly aided in the screening of non-palpable breast lesions, with emphasis on mammography, which identifies micro-calcifications, asymmetries and nodules, and on mammary ultrasonography, which is the most commonly used complementary method to characterize mammographic findings or to assist in the investigation of dense breasts.

These findings must be standardized regarding the conduct, mainly based on the morphological characteristics of the lesions found in the imaging tests. To this end, the American College of Radiology, the National Cancer Institute (NCI), the Centers for Disease Control and Prevention (CDC), the Food and Drug Administration (FDA), the American College of Surgeons and the American College of Pathologists have created a system to standardize radiology reports when analyzing breast imaging, the Breast Imaging-Reporting and Data System (BIRADS ${ }^{\circledR}$.

The importance of this classification is mainly due to the easy way of separating benign lesions from potentially malignant lesions (according to their mammographic, ultrasonographic or magnetic resonance features) and their acceptable correlation with the histopathological findings.

The identification of lesions suspected of malignancy determines the need of cytological or histopathological evaluation through a minimally invasive procedure, whose arsenal consists basically of fine-needle aspiration (FNAB) or core-biopsy; in discordant cases, the open biopsy is used to determine the definitive diagnosis of the lesion ${ }^{1-3}$.

Current data point to reliability of the BIRADS ${ }^{\circledast}$ classification for the professional in making decisions regarding the conduct of breast lesions, based on the possibility of a particular lesion being benign or malignant, and in analyzing its imaging features in order to treat each patient properly and in time.

The purpose of this study is to correlate the imaging findings of breast lesions with a definitive diagnosis confirmed by a histopathological study, demonstrating the high predictive value of the BIRADS ${ }^{\circledR}$ classification and evaluating the impact of these findings on surgical intervention. Moreover, this correlation between the two exams may avoid unnecessary procedures, as to typically benign lesions, or may alert to the urgency of treatment in those with higher chances of malignancy, according to the imaging characteristics.

The aim of this study was to correlate imaging features of breast nodules, evidenced by ultrasonography and classified according to BIRADS $^{\circledR}$, with the results of histopathological examination of materials obtained through thick-needle biopsy and incisional biopsy, when performed, of patients from the outpatient clinic of mastology at the Maternity School Assis Chateaubriand.

\section{METHODS}

\section{Type of study and sample}

This is a retrospective, quantitative and descriptive study carried out through the record evaluation from patients attended at the Outpatient Clinic of the Maternity School Assis Chateaubriand who underwent breast biopsy using a thick needle between January 2015 and January of 2016 . We searched the medical records from 136 patients seen at the Benign Pathology Clinic of the institution.

\section{Data collection and analysis}

The procedures recorded in the Ultrasonography Service were cataloged according to the performance of ultrasound guided biopsy, excluding FNAB and pre-surgical marking of the impalpable lesion, obtaining a list of medical records that would be analyzed.

A specific form was applied with clinical-epidemiological questions of the patients and evaluation of the imaging characteristics of the breast nodules seen in the ultrasonography, as well as the result of the histopathological examination.

The collected data were stored in tables in the Microsoft Excel program for correlation of the values, which were later statistically analyzed. The graphs and tables of the present study were also generated in the same program.

\section{Inclusion criteria}

Patients who underwent thick needle biopsy in the Ultrasonography Service of the Maternity School Assis Chateubriand were evaluated at a subsequent medical visit for the results of the anatomopathological report and pertinent conduct guidance.

\section{Exclusion Criteria}

Patients with incomplete data on the patient's medical record were excluded from the study, such as absence of a pathological examination result and non-BIRADS ${ }^{\circledR}$ ultrasonographic classification in the exam that generated the biopsy request, or patients who abandoned treatment/follow-up at the institution, as well as patients who underwent FNAB. In total, 26 patients were excluded.

\section{Ethical aspects}

The Maternity School Assis Chateaubriand Research Ethics Committee approved the project, with approval number 1.869.537.

\section{RESULTS}

\section{Patient population}

We analyzed 110 medical records that fit the inclusion criteria. According to the ultrasonographic features of breast lesions, only one case was classified as BIRADS ${ }^{\circledR} 2$ (biopsy due to the patient's personal history), corresponding to $0.9 \%$ of the total; 46 cases (41.8\%) were classified as BIRADS $^{\circledR} 3 ; 55(50 \%)$ as BIRADS $^{\oplus} 4$, thus 
distributed into: $4 \mathrm{~A}$ in $32.7 \%$; $4 \mathrm{~B}$ in $9.1 \%$; $4 \mathrm{C}$ in $2.7 \%$; and $5.4 \%$ without described subdivision (Figure 1). Furthermore, eight cases $(7.7 \%)$ were classified as BIRADS ${ }^{\circledR}$. Among the patients with BIRADS ${ }^{\circledR}$ 3 , all the histopathological results were from benign breast lesions.

After evaluating the medical records, we observed that the mean age of the patients who entered the inclusion criteria for the study was 46.09 years.

Only $11 \%$ of the patients had a family history of breast cancer and $3.6 \%$ had a personal history of the disease. Patients who
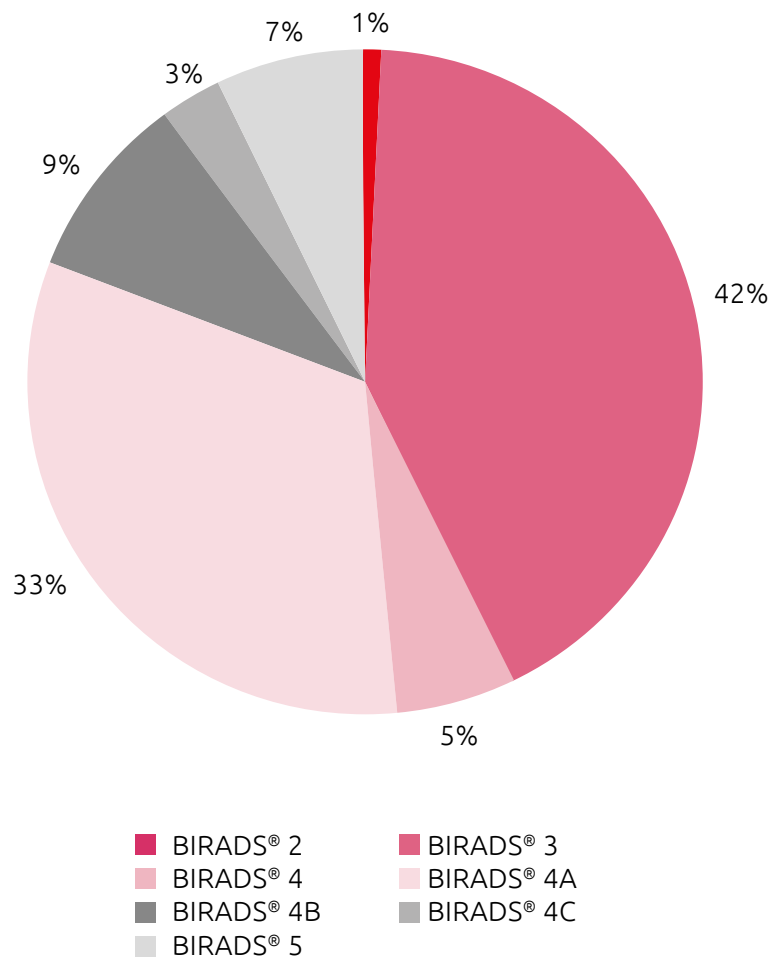

Figure 1. BIRADS ${ }^{\circledR}$ ultrasonographic classification of the study patients.

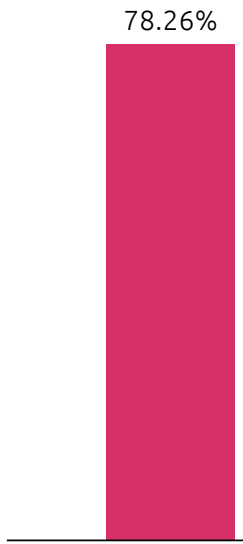

Fibroadenoma

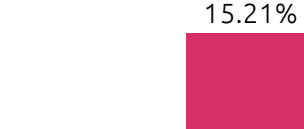

Fibrosis underwent mammography presented BIRADS ${ }^{\circledR} 0$ classification in $42.7 \%$ of the cases, suggesting diagnostic complementation for having presented lesion to this method. Most of the biopsied lesions were impalpable (59.1\%) and about $42.7 \%$ underwent surgery to remove the nodule.

\section{BIRADS ${ }^{\circledR} 3$ Group}

Patients with solid breast lesions with regular, circumscribed margins, precise limits and no posterior acoustic shade were classified as BIRADS $^{\circledR} 3$. The mean age of these patients was 44.06 years. All the lesions presented benign features in the biopsy result, as well as in the product of the surgical specimen of the lesions (Figure 2).

Approximately $21.7 \%$ of the patients underwent surgical excision of the lesion, and benign lesions were found in all cases (seven fibroadenomas, one adenosis, one benign phylloid tumor and one fibrosis).

Most of the lesions were impalpable; that is, they were detected only in imaging tests (69.6\%). Approximately $47.8 \%$ of the patients who underwent mammography were classified as $\mathrm{BIRADS}^{\circledR} 0$, suggesting the conduction of ultrasonography.

\section{IRADS ${ }^{\circledR} 4$ Group}

Breast nodules presenting lobular or irregular margins, poorly defined limits, presence of posterior or lateral acoustic shadow and cystic areas were classified as $\operatorname{BIRADS}^{\circledR} 4$, which were subdivided into A, B or C, depending on the degree of these features.

In some records, this sub-classification was omitted by the examiner or radiologist who made the examination report; these patients accounted for $5.4 \%$ of the sample. In half of the cases, the histopathological result of the biopsy and surgical specimen was invasive breast carcinoma; the other half resulted in benign lesions.

The lesions subclassified as BIRADS ${ }^{\circledR} 4$ A also presented benign lesions in the histopathological analysis, with a total of $97.3 \%$ of

Figure 2. Histopathological results of lesions classified as BIRADS ${ }^{\circledR} 3$. 
the findings (Figure 3). Only one patient presented a complex sclerosing proliferative lesion in the thick needle biopsy, which later confirmed carcinoma in situ in the surgical specimen. In approximately $75 \%$ of the patients, the lesion was impalpable.

Nodules with characteristics of moderate suspicion, classified as BIRADS ${ }^{\circledR} 4 \mathrm{~B}$, represented $9.1 \%$ of the sample. Of the thick needle biopsies, $50 \%$ resulted in invasive carcinoma after histopathological analysis, $10 \%$ of lesions were at risk and $40 \%$ of benign lesions. After surgical removal of the lesions, a case of flat epithelial atypia, diagnosed in fragment biopsy, presented areas of invasive carcinoma in the surgical specimen (Figure 4). The majority of cases (60\%) were of impalpable lesions and $30 \%$ were also classified as BIRADS ${ }^{\circledR} 4$ on mammography.

Only $2.7 \%$ of the patients had a breast lesion classified as high suspicion of malignancy (BIRADS ${ }^{\circledR} 4 \mathrm{C}$ ). In all cases, invasive carcinoma was diagnosed in the thick needle biopsy and in the surgical specimen. The lesions were all palpable, although only one-third were larger than $2 \mathrm{~cm}$ in size at ultrasonography.

\section{BIRADS ${ }^{\circledR} 5$ Group}

A little more than $7 \%$ of the patients presented lesions with ultrasound characteristics highly suggestive of breast neoplasm, classified as BIRADS ${ }^{\circledR} 5$. Only one case did not confirm invasive carcinoma, resulting in fibrosis (Figure 5). All lesions were palpable, although $87 \%$ measured between 1 and $2 \mathrm{~cm}$ by imaging examination. About $37.5 \%$ of the mammograms also presented a highly suspected lesion.

\section{DISCUSSION}

According to the sixth edition of the BIRADS ${ }^{\circledR}$ system, the lesion categories are divided as follows:

- Category 0: needs additional imaging or previous exams for comparison;

- Category 1: negative;

- Category 2: benign findings;

- Category 3: probably benign;

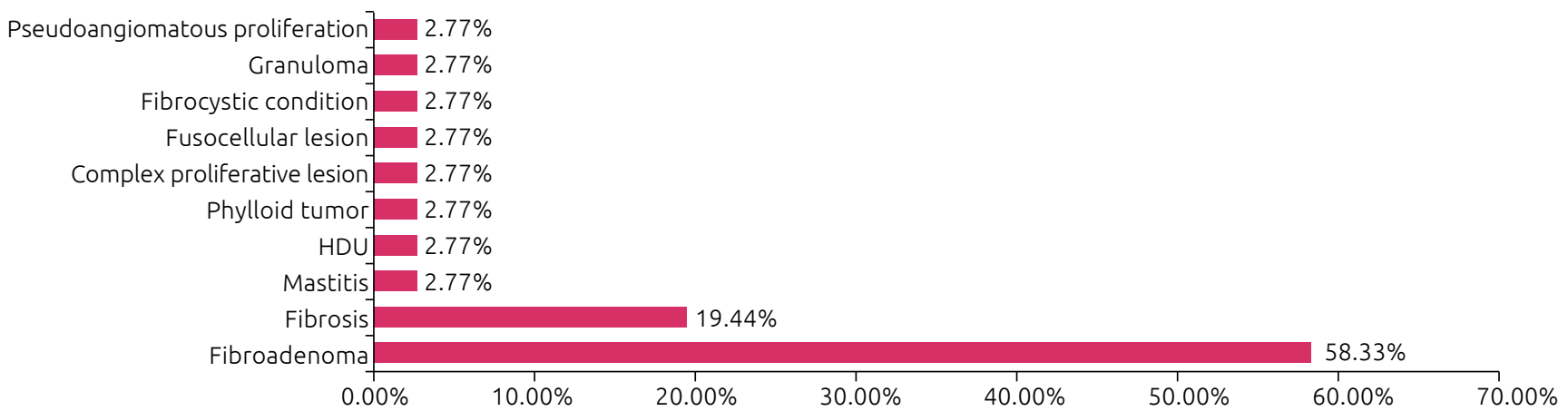

Figure 3. Histopathology of lesions classified as BIRADS ${ }^{\circledR} 4$ A.

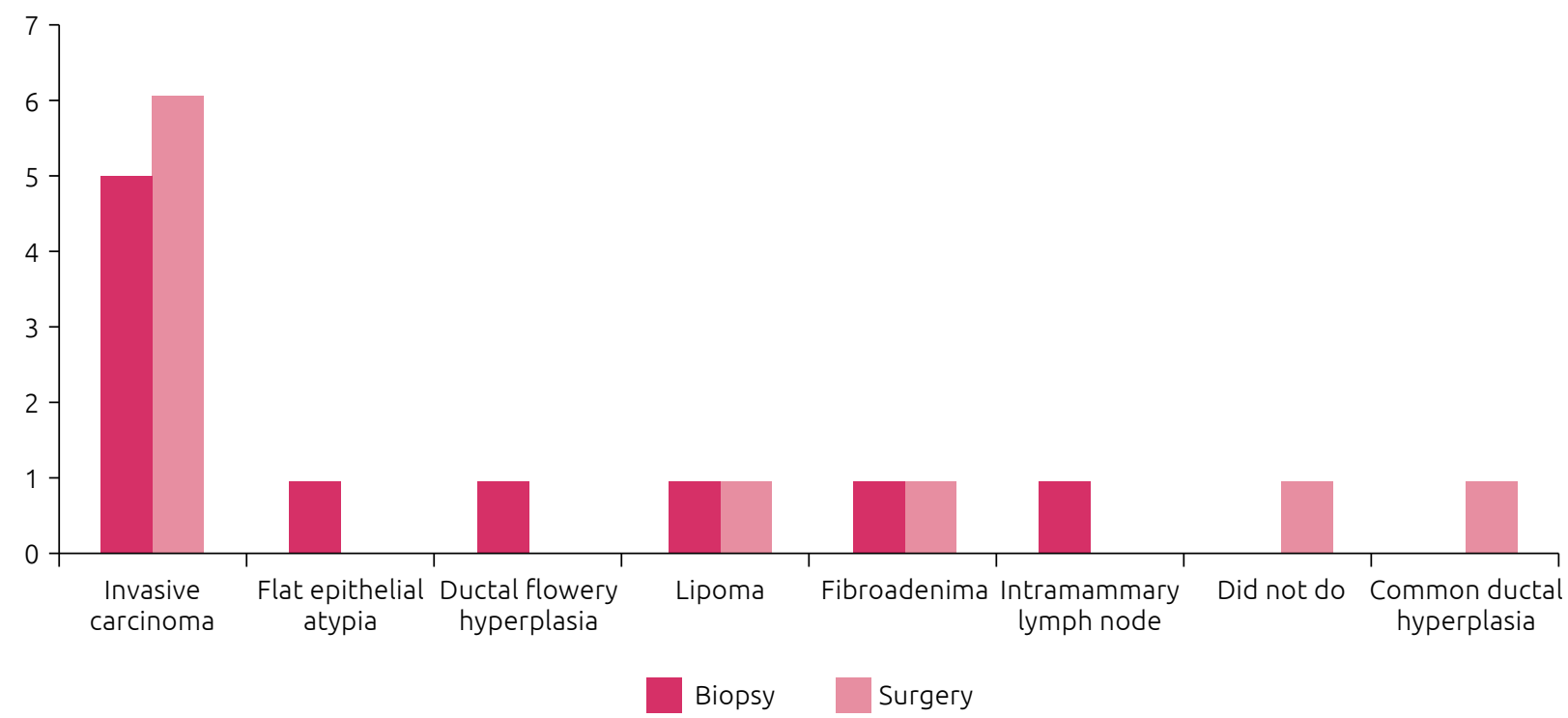

Figure 4. Histopathology of lesions classified as BIRADS ${ }^{\circledR} 4 B$. 


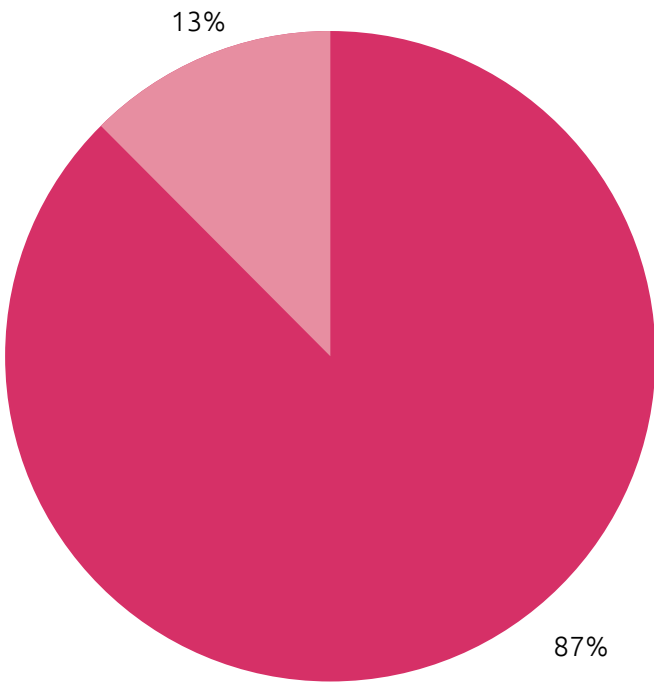

Invasive carcinoma Fibrosis

Figure 5. Histopathology of lesions classified as BIRADS ${ }^{\circledR} 5$.

- Category 4A: low suspicion of malignancy;

- Category 4B: moderate suspicion of malignancy;

- Category 4C: high suspicion of malignancy;

- Category 5: highly suggestive of malignancy and

- Category 6: malignancy proven by biopsy ${ }^{4}$.

The malignancy estimate, according to BIRADS ${ }^{\circledR}$, ranges from $2 \%$ for category 3 lesions up to $95 \%$ for those classified as category 5 .

The results obtained in the research are close to those found in the literature and corroborate the behaviors already used in clinical practice. When the nodule presents ultrasound characteristics, such as regular margins, defined limits and absence of posterior acoustic shadow, the greater probability is that it is a benign lesion, which enables only one follow-up, thus avoiding costly and uncomfortable procedures to the patient.

However, the breast lesions cases with unfavorable ultrasound characteristics, which point to a greater probability of breast cancer diagnosis, require an energetic propaedeutic for a more efficient treatment.

The positive predictive value of category 5 reaches $100 \%$ in some studies ${ }^{5}$. A research found $100 \%$ agreement between the findings characterized as BIRADS ${ }^{\circledR} 5$ and the anatomopathological result ${ }^{6}$. Onur et al. found a sensitivity and specificity of $93.5 \%$ and $100 \%$, respectively, in core biopsy results, when correlated with mammographic BIRADS ${ }^{\circledR 7}$.

The classification of BIRADS ${ }^{\circledR} 4$ A diagnoses a higher percentage of benign lesions, that is, less than $5 \%$ of malignancy. In the present study, benignity was identified in almost $100 \%$ of these patients, which brings us the questioning in the biopsy procedure in all these cases. However, the current conduct of BIRADS ${ }^{\circledR}$ does not allow us to omit biopsy in these cases. Some had incomplete sub-classification information, among which there were cases of breast carcinoma, not giving us certainty that this group of patients would benefit from clinical follow-up only.

In the present study, the fragment biopsy procedure in mammary lesions with a benign anatomopathological diagnosis, especially in those classified as BIRADS $^{\circledast} 4 \mathrm{~A}$, had a positive impact on the reduction of the surgical approach and a relevant implication in the reduction of costs in health services.

\section{CONCLUSION}

In conclusion, the ultrasound features of breast lesions have a high predictive value in the final diagnosis, mainly in nodules with benign characteristics in the image examination, which is a fundamental datum for the decision of conduct in an adequate time in each situation.

\section{REFERENCES}

1. Araújo FM, Albuquerque PS, Alves ACBR, Pinto LSS. Avaliação das características mamográficas, ultrassonográficas e histopatológicas de uma série de lesões neoplásicas malignas de origem epitelial da mama. Rev Epidemiol Controle Infecção. 2015;5.

2. Rao AA, Feneis J, Lalonde C, Ojeda-Fournier H. A pictorial review of changes in the BI-RADS Fifth Edition. RadioGraphics. 2016;36.

3. Dobruch-Sobcrzak K. The differentiation of the character of solid lesions in the breast in the compression sonoelastography. Part II: Diagnostic value of BIRADS - US classification, Ysukuba score and FLR ratio. J Ultrasonography. 2013;13.

4. Moreno M, Miranda MHF, Hernandes Júnior CG. Utilização de Ultrassonografia para o seguimento de lesões mamárias benignas avaliadas por citologia. Rev Bras Mastologia. 2015;25.
5. Lippi VG, Silva TLN, Sacco AC, Venys GL, Lima MCN, Ciantelli GL. Correlação radiológica e histológica utilizando o sistema BI-RADS: valor preditivo positivo das categorias 3, 4 e 5 . Rev Fac Ciênc Méd Sorocaba. 2014.

6. Marques LO, Nascimento GBN, Wiederkehr BA, Silva DJM, Kamei DJ, Santos FMR, et al. Correlação dos achados clínicos, mamográficos e ultrassonográficos do carcinoma ductal isolado ou associado a outras neoplasias. Rev Med Res. 2014;16(2):99-107.

7. Onur GO, Tarcan E, Onur A, Can H, Atahan MK, Yigit SC, et al. Comparison between radiological and invasive diagnostic modalities in diagnosis of breast cancer. Asian Pac J Cancer Prev. 2015;16. 